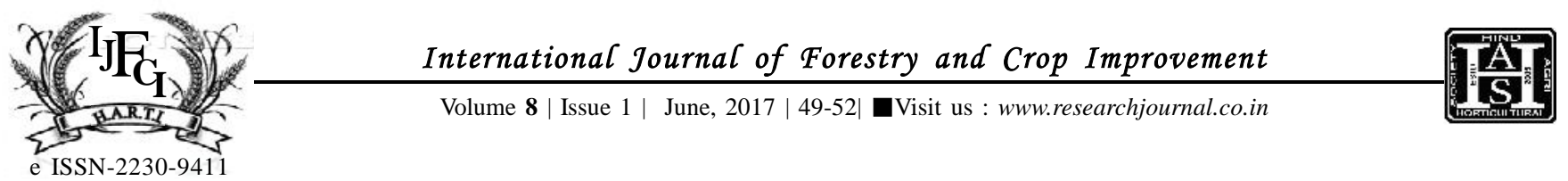

RESEARCH ARTICLE

DOI: $10.15740 / \mathrm{HAS} / \mathrm{IJFCI} / 8.1 / 49-52$

\title{
Performance of inter specific cotton hybrids under various plant geometries and nutrient levels
}

\author{
HARPHOOL MEENA AND BHERU LAL KUMHAR
}

\begin{abstract}
Field experiment was conducted at Agricultural Research Station, Borwat Farm, Banswara during Kharif-2010 to find out the optimum plant geometry and fertility levels for inter specific cotton hybrids with three cotton hybrids (JKCHB214,RAHB-170 and DCH-32), two plant geometries ( $90 \times 60$ and $90 \times 45 \mathrm{~cm}$ ) and three fertility levels (75,100 and $125 \%$ RDF). Sowing of JKCHB-214 cotton hybrid gave significantly higher seed cotton yield $\left(1558 \mathrm{~kg} \mathrm{ha}^{-1}\right)$ over DCH-32 cotton hybrid. The maximum seed cotton yield $\left(1754 \mathrm{~kg} \mathrm{ha}^{-1}\right)$ was observed under wider plant geometry of $90 \times 60 \mathrm{~cm}$ than closer plant geometry of $90 \times 45 \mathrm{~cm}$. Though, yield attributing parameters such as bolls plant ${ }^{-1}$ and boll weight were statically improved in wider as compared to closer spacing it could be increase the seed cotton yield. Among fertility levels, similar seed cotton yield was recorded with the application of 100 per cent RDF $\left(1555 \mathrm{~kg} \mathrm{ha}^{-1}\right)$ and 125 per cent $\operatorname{RDF}\left(1602 \mathrm{~kg} \mathrm{ha}^{-1}\right)$ but both were significantly better than that of 75 per cent RDF and plant geometry $90 \times 60 \mathrm{~cm}$ seemed to be ideal for inter specific hybrid cotton for realizing higher productivity under the specific agro climatic zone IV $b$ of Rajasthan.
\end{abstract}

KEY WORDS : JKCHB-214, Inter specific cotton, Plant geometry, Fertility levels

How TO CITE THIS ARTICLE : Meena, Harphool and Kumhar, Bheru Lal (2017). Performance of inter specific cotton hybrids under various plant geometries and nutrient levels. Internat. J. Forestry \& Crop Improv., 8 (1) : 49-52, DOI: 10.15740/HAS/IJFCI/8.1/49-52.

ArTiCle Chronical : Received : 01.04.2017; Revised : 07.05.2017; Accepted : 21.05.2017

MEMBERS OF RESEARCH FORUM

Address of the Correspondence : HARPHOOL MEENA, Agricultural Research

Station Ummedganj Farm, Agriculture University, KOTA (RAJASTHAN) INDIA

Email: hpagron@ rediffmail.com

Address of the Coopted Authors : BHERU LAL KUMHAR, Agricultural Research

Station Ummedganj Farm, Agriculture University, KOTA (RAJASTHAN) INDIA 